\title{
Cognitive Bias and Risk Preferences Analysis of Ponzi Scheme Investors
}

\author{
Maya Sari, Nugraha \\ Management Study Program \\ Universitas Pendidikan Indonesia \\ mayasari@upi.edu
}

\begin{abstract}
The form of Ponzi scheme has evolved over many years and continues to change shape.The interesting phenomenon from such as Ponzi Scheme is that although many investors have lost their money, as publicized in the mass media, the case still continued until now. This study aims to gain an overview of cognitive bias, and risk preference. Furthermore, the relations between these factors and investment decisions of Ponzi Scheme Investors are also examined. The cognitive bias studied includes overconfidence, availability heuristic, and herding while the risk preference parameter used is risk tolerance. The respondents consisting of 115 Ponzi scheme investors, are taken using purposive sampling method. The verification analysis used is multiple linear regressions. The result shows that overconfidence, availability, herding and risk preference are the main principal basis in processing the information to make financial decisions. Overconfidence, availability heuristic, herding, and risk tolerance, have a positive and significance influence toward investment decision. Among the four variables, Overconfidence is the factor that has the greatest influence to the decision to invest This study hopefully will help investors to be aware of the impact of their own psychological factors in their investment decision.
\end{abstract}

Keywords : Overconfidence, Availability heuristic, Herding, Risk Tolerance

\section{BACKGROUND OF THE STUDY}

Ponzi scheme or HYIP (High-Yield Yield Investment Program) has evolved over many years and continues to growth [1]. This investment usually promises a great return but, in fact, it is not high returns obtained by investors and in some cases; the investor loss all of their money. The interesting phenomenon from such this investment is that although many investors have lost their money, as publicized in the mass media, the case still continued until now.

The study of behavioral finance allows cognitive psychology to play a potentially important role in finance. This approach offers a better explanation of relevant factors that influence investment decision's Ponzi scheme than the neoclassical economic approach [2]. Behavioral finance approach is explained that people are not always rational in taking financial decision as there are cognitive bias and emotional factors [3].

The cognitive bias studied includes overconfidence, availability heuristic, and herding. Overconfidence is a belief that he has more abilities and knowledge than others.
Overconfident investors tend to perceive themselves to be more competent, and thus are more willing to act against their beliefs, leading to more investment [4].

Another belief factor that influence the investment decision is availability heuristic which shows a tendency to rely more on available information at the time of decision making, which makes the decision making spontaneous and tends to choose investment decisions that are familiar. The availability bias has a positive significant impact on investors' decision making because investors generally depend highly on easily available information [5].

Herding is also a form of cognitive bias done by the investors where they base their investment decision not by considering the economic fundamental basis of assets at risk, but, by looking at the actions of other investors in the same circumstances or even. Investors who do not have the information tend to show herding behavior, where they will act reactive to the investment choices of the investors who are considered to have the information [6].

Besides that irrationality which is attributed to the belief can also occur due to individual preferences towards risk [7]. Risk tolerance is one of the parameters of risk preference, which shows the level of investor tolerance to the risk of the investment. Investor with a higher-risk tolerance will invest more on a high-risk investment. Otherwise, investor with a lower-risk tolerance will invest more on low-risk investment [8],[9].

Advocates of behavioral finance have been able to explain a number of cognitive bias and risk preference that affect the investment decision. The findings from some studies showed that overconfidence, availability bias, herding and risk preference have significant impacts on the investors' decision making [10] [11].

The main purpose of this research is to investigate how the overconfidence, availability bias and herding and risk preference could possibly affect the financial decision on Ponzi Scheme. As there are limited studies about behavioral finance in Indonesia, this study is expected to contribute significantly to the development within this field. 


\section{LITERATURE REVIEW}

Finance behavior point of view believes that conventional financial theory ignores the way people make their decision and how it differs from one and another. In this approach, the investors are often considered irrational in taking financial decision as there are cognitive bias and emotional factors.

Overconfidence is a belief that someone has an over average ability and knowledge [12]. Investor who has high overconfidence intend to overestimate their knowledge and underestimate risk which lead them to take the wrong position in the transaction [13]. Overconfident investors will trade too frequently, that is, the gains overconfident investors realize through trade will be less than they anticipate and may not even offset the costs of trading [14].

Heuristic means showing an effort to process information quickly based on insufficient experience and intuition. One of the heuristic factor in financial decision making is availability. The availability heuristic refers to the phenomenon of determining the likelihood of an event according to the easiness of recalling similar instances. In other words, the availability heuristic may be described as a rule of thumb, which occurs when people estimate the probability of an outcome based on how easy that outcome is to imagine [15].

Availability heuristic shows a tendency to rely more on available information at the time of decision making,which made the decision making spontaneous and tends to choose investment decisions that are familiar [16].

Herding is usually termed as the behavior of an investor imitating the observed actions of others or the movements of the market instead of following her own beliefs and information [17]. The investor decision can influence another investor's decision in terms of selling, purchasing, selecting stock, investment period and the volume of investment [18].

The hope of an investor to invest in is to get the maximum expected return from the amount of funds invested. However, to obtain the expected return, an investor faced with uncertainty (risk), so take optimal investment decisions, both factors must be considered together, because of the trade-off between expected return and risk. Investors' risk preferences will influence the choice of alternative decisions. Prospect theory explains that investors tend to frame the choice of investment decisions in the context of potential gains and losses based on specific preferences [19]. Based on the theory, investors have an irrationality tendency as they are reluctant to risk profits to losses.

\section{RESEARCH METHODS}

This study was conducted to obtain empirical evidence on the factors of cognitive biases and risk preferences that affect the investment decisions. Descriptive research in this study was conducted to identify factors, which become the primary identifier of the cognitive biases owned by Ponzi scheme investors and their risk preferences. While the verification study was conducted to examine the interrelationship between cognitive biases, risk preferences and the decision to invest in Ponzi scheme. The verification analysis will be conducted through multiple linear regression analysis. In multiple linear regression analysis, there are three criteria for goodness of fit, the $\mathrm{t}$ test, $\mathrm{F}$ test, and the determination coefficient. Before the multiple linear regression analysis, there was a classical assumption test of multicollinearity test, heteroscedasticity, and autocorrelation.

The research method used is a survey explanatory. The time horizon of this study is cross-sectional, a study in a specific time period but performed on several subjects. The equation of this model is

$$
\begin{aligned}
\text { Investment decision }= & a+b_{1} \text { overconfidence }+b_{2} \\
& \begin{array}{l}
\text { availability }+b_{3} \text { herding }+b_{4} \text { risk } \\
\text { preference }+e_{1}
\end{array}
\end{aligned}
$$

The population of the study was the Ponzi scheme investors in Bandung, and the sampling technique used was purposive random sampling. Samples in this study were selected based on the 115 questionnaires returned by the respondents and filled completely.

The data in this study was collected using a checklist questionnaire / enclosed statement that was distributed via email, and / or delivered directly to the respondents

\section{DATA ANALYsis}

The majority of Ponzi scheme investors in Bandung were 52.2 percent male, while the remaining $47.8 \%$ were women. Meanwhile, according to age, the majority of respondents were $65.2 \%$ reproductive age or 41 years - 50 years, while the rests are less than 40 years $(17.4 \%)$ and age above 50 years $(17.4 \%)$. In addition, $65.2 \%$ were married and the remaining $34.8 \%$ have not / were not married. Based on the level of education held by the respondents, the majority were bachelor (S1) degree level $(80.9 \%)$ and only $1.7 \%$ were S2 educated. In addition, $65.2 \%$ were self-employed, while the remaining $17.4 \%$ respectively were BUMN employee and private employees who $82.6 \%$ had worked between five years to 10 years while the remaining $17.4 \%$ have worked for more than 10 years.

The amount of incomes received by the majority of respondents were $47.8 \%$ less than Rp. 3 million per month, and only $17.4 \%$ who earn more than Rp. 12 million per month The majority of respondents, $82.6 \%$ had only an investment in the form of Ponzi scheme alone while the rest, in addition to having an investment Ponzi scheme, had other investments in land and gold (17.4\%). The majority of respondents, $82.6 \%$ were promised to get higher rates of return 16\%-20\%. A total of 52.2\% got their benefit from the funds they invested. As for the remaining $47.8 \%$ got their benefit from the funds they invested and from recruiting new investors. Based on the amounts invested, the majority of respondents, $47.8 \%$ invested 
more than Rp. 10 million, while the rest is invested in varying amounts. $52.2 \%$ invested within a period of one year to two years while the remaining $47.8 \%$ only invest in a period of less than.

The measurement results show the respondents over confidence is high. It can be seen that the respondents perception of expectations of success is expressed the highest by the respondents while the lowest respondents rating is the perception of the ability to provide investment advice. High level of confidence in the form of overconfidence causes investors tend to overestimate the knowledge, and underestimate the risk. Findings related to the high level of overconfidence among Ponzi investment in line with the research which states that in the worst conditions overconfident investors are victims of fake investments like Ponzi scheme [20].

The availability heuristic among investor of the Ponzi scheme investment is the high category. The high level of confidence in the form of availability heuristic is mainly due to the perception of respondents who Ponzi investments can increase wealth quickly. Additionally, the availability heuristic belief is high because the majority of respondents were firsttime investors in a Ponzi investment so that they have a limited ability and experience that ultimately led investment decision making to rely solely on the information available at that time. This finding is in line with argument the heuristic usually happens to someone when they face something for the first-time [21].

Herding is one form of investor's irrational behavior where they take their investment decisions by not considering the economic fundamental basis of an asset at risk, but by looking at the actions of other investors in the same circumstances or even by following the market consensus. Belief in the form of herding is also found in this study. In fact, the results show herding beliefs are included in the high category. Belief in the form of herding can be seen especially from the high number of respondents who have a perception that the decision to accept / reject made by friends / relations affect their decision to invest. High level of herding, indicating that the role of friends or family is relatively high when considering the Ponzi investment decisions. This condition is relevant to the findings of other studies in which the majority of respondents investing Ponzi scheme because of solicitation relation [22].

The measurement of Risk tolerance as one of the parameters of risk preference showed in the high category. A high level of the risk tolerance means that the acceptance of risk is higher than investors with low risk tolerance. The description of Risk Tolerance owned by Ponzi scheme investor results showed that the majority of respondents have a high level of acceptance of risk, or they are more receptive to high-risk investments. It reflects that the majority of investors are a risk taker. This finding is relevant with other studies in which they are willing to invest at high risk because the previous investment experience was profitable. [23].
The results of research related to the Ponzi scheme investment decisions fall into the high category. The majority of respondents agreed that the decision to invest in a Ponzi provided high expected return. It was primarily because the respondents gained the high return from their investment, as promised, level of benefits exceeds the average return on investment in general. Although the perceived level of satisfaction is not optimal, it is due to the high rate of return is felt only in the short term, hence forth they can no longer enjoy such benefits because these benefits were terminated unilaterally by the management. Another dissatisfaction factor is that many investors, after enjoying the advantage for a while, should lose all the funds invested. This condition is relevant to the findings of other studies [24].

TABLE I. RELATION BETWEen Bias KogNitif, RisK PREFERENCE AND INVESTMENT DECISION

\begin{tabular}{|c|c|c|c|}
\hline \multirow{2}{*}{ Model } & \multicolumn{3}{|c|}{ Multiple linear regression analysis } \\
\cline { 2 - 4 } & Coeficient & t-ratio & P-Value \\
\hline Cost & 2.009 & 4.342 & 0.000 \\
\hline Overconfidence & 0.174 & 2.215 & 0.029 \\
\hline Availability & 0.171 & 3.382 & 0.001 \\
\hline Herding & 0.081 & 2.013 & 0.047 \\
\hline Risk Preference & 0.082 & 0.014 & 0.046 \\
\hline F-Value & \multicolumn{3}{|c|}{$\mathbf{7 6 . 7 4 8}$} \\
\hline Adj R2 & $\mathbf{0 . 7 3 6}$ \\
\hline
\end{tabular}

Table I showed the relation between bias cognitive, risk preference and investment decision. The test results showed that simultaneously, Overconfidence, Availability, Herding, and the risk tolerance have a significant influence on Investment Decision ( $\mathrm{F}=76,748$, with a significance level of $0.000<0.05)$. Similarly, the partial test results showed that Overconfidence, Availability, Herding, and risk tolerance had partial influence on Investment Decision (sig <0.05). Among the four variables, Overconfidence is the factor that has the greatest influence to the decision to invest. The value of $\mathrm{R}$ Square $=0,736$ illustrates that the contribution of Overconfidence, Availability, Herding, and risk tolerance to fluctuations in Investment Decision variable is equal to73. $60 \%$ and the remaining $26.40 \%$ are contributed by other variables not included in the model proposed in the study. The results of multiple linear regression analysis showed that overconfidence, availability, herding and risk tolerance have positive influence toward investment decisions. This condition is relevant to the findings of other studies that the higher the overconfidence, availability, herding, and risk preference, the higher the investment decision [25], [26].

\section{CONCLUSIONS AND SugGeStions}

This study aims to examine the influence of cognitive biases and risk preference on investment decision using a sample of 115 investors Ponzi Scheme. The results showed that overconfidence, availability, herding and risk tolerance have a positive and significant influence toward investment decisions. The partial test results showed that overconfidence 
are the main factors that influence the decision to invest in Ponzi scheme.

This study hopefully will help investors to be aware the impact their own psychological factors in their investment decision.

\section{REFERENCES}

[1] Vasek M, Moore T. There's No Free Lunch, Even Using Bitcoin: Tracking the Popularity and Profits of Virtual Currency Scams. InInternational Conference on Financial Cryptography and Data Security 2015 Jan 26 (pp. 44-61). Springer Berlin Heidelberg.

[2] Detzer D, Herr H. Theories of financial crises-an overview. Institute for International Political Economy Berlin, Working Paper. 2014(32)

[3] Aggarwal R. Animal spirits in financial economics: A review of deviations from economic rationality. International Review of Financial Analysis. 2014 Mar 31;32:179-87

[4] Mota JH, Moreira AC, Cossa AJ. Behavioural factors in the financial decisions of young Mozambicans. South African Journal of Business Management. 2015 Dec 1;46(4):11-22

[5] Kremer S, Nautz D. Causes and consequences of short-term institutional herding. Journal of Banking \& Finance. 2013 May 31;37(5):1676-86

[6] Damodaran A. Living with Noise: Investing and Valuation in the Face of Uncertainty. Available at SSRN 2323621. 2013 Jul 10

[7] 7Plott CR, Zeiler K. The Willingness to Pay-Willingness to Accept Gap, the "Endowment Effect," Subject Misconceptions, and Experimental Procedures for Eliciting Valuations: Reply. The American Economic Review. 2011 Apr 1;101(2):1012-28

[8] Hanna SD, Guillemette MA, Finke MS. Assessing risk tolerance. Portfolio Theory and Management. 2013 Mar 7:99-120

[9] Gilliam J, Chatterjee S, Grable JE. Measuring the perception of financial risk tolerance: A tale of two measures. Journal of Financial Counseling and Planning. 2010;21(2)

[10] Chater N, Huck S, Inderst R. Consumer decision-making in retail investment services: A behavioural economics perspective. Report to the European Commission/SANCO. 2010 Nov 22.

[11] Ngoc LT. Behavior pattern of individual investors in stock market. International Journal of Business and Management. 2014 Jan 1;9(1):1

[12] Merkle C. Financial overconfidence over time-foresight, hindsight, and insight of investors. InAFA 2013 San Diego Meetings Paper 2013 Aug 31

[13] Glaser M, Weber M. Overconfidence and trading volume. The Geneva Risk and Insurance Review. 2007 Jun 1;32(1):1-36
[14] Blake D, Boardman T. Spend More Today Safely: Using Behavioral Economics to Improve Retirement Expenditure Decisions With SPEEDOMETER Plans. Risk Management and Insurance Review. 2014 Mar 1;17(1):83-112

[15] Kliger D, Kudryavtsev A. The availability heuristic and investors' reaction to company-specific events. The Journal of Behavioral Finance. 2010 Mar 9;11(1):50-65

[16] Jain R, Jain P, Jain C. Behavioral Biases in the Decision Making of Individual Investors. IUP Journal of Management Research. 2015 Jul $1 ; 14(3): 7$

[17] Saxena S, Purohit H, Satija VD. Retail Investors' Herding Behaviour: Determinant of. SCMS Journal of Indian Management. $2016 \mathrm{Apr}$ $1 ; 13(2)$

[18] Kengatharan L, Kengatharan N. The influence of behavioral factors in making investment decisions and performance: Study on investors of Colombo Stock Exchange, Sri Lanka. Asian Journal of Finance \& Accounting. 2014 Jun 1;6(1):1

[19] Barberis NC. Thirty years of prospect theory in economics: A review and assessment. The Journal of Economic Perspectives. 2013 Feb 1;27(1):173-95

[20] Elan SL. Behavioral patterns and pitfalls of US investors. InFederal Research Division, Library of Congress 2010

[21] Benartzi S, Thaler RH. Heuristics and biases in retirement savings behavior. The journal of economic perspectives. 2007 Aug 1;21(3):81104

[22] Nash R, Bouchard M, Malm A. Investing in people: The role of social networks in the diffusion of a large-scale fraud. Social Networks. 2013 Oct 31;35(4):686-98

[23] Fellner G, Sutter M. Causes, consequences, and cures of myopic loss aversion-An experimental investigation. The Economic Journal. 2009 Apr 1;119(537):900-16

[24] Schulmerich M, Leporcher YM, Eu CH. Explaining Stock Market Crashes: A Behavioral Finance Approach. InApplied Asset and Risk Management 2015 (pp. 355-413). Springer Berlin Heidelberg.

[25] Shafi M. Determinants influencing individual investor behavior in stock market: a cross country research survey. Arabian Journal of Business and Management Review. $2014 \mathrm{Feb}$;2(1):60-71.

[26] Noussair CN, Trautmann ST, Van de Kuilen G. Higher order risk attitudes, demographics, and financial decisions. The Review of Economic Studies. 2014 Jan 1;81(1):325-55. 